\title{
How Much Did The Gulf Oil Spill Actually Cost British Petroleum Shareholders?
}

\author{
Denis O. Boudreaux, Ph.D., University of Louisiana, USA \\ SPUma Rao, Ph.D., University of Louisiana, USA \\ Praveen Das, University of Louisiana, USA \\ Nancy Rumore, University of Louisiana, USA
}

\begin{abstract}
On April 20, 2010, the Deepwater Horizon Drilling Platform, a British Petroleum (BP) licensed rig, exploded. Two days later the huge rig sank to the bottom of the Gulf of Mexico triggering the United States worst offshore oil spill. By April 26, investors and the market began realizing that the costs associated with this catastrophic event to BP could be significant and BP shares fell by over two percent. The next day BP reported its annual earnings which showed a huge rise in profits, due in part to much higher oil prices for the previous year and BP's common stock price increased. However, on May 6, 2010, analysts warned that the Gulf of Mexico oil spill disaster would likely cost BP over $\$ 23$ billion dollars ( $£ 15 \mathrm{bn}$ ) and its shares can be expected to lag behind those of its competitors by 5\% for the lasting future. At the same time, Tony Hayward insisted the company would "bounce back" from the setback though he could not give a timescale for when the flow of oil would be halted. This study investigated BP's stock returns using two models to determine if their stocks experienced abnormal returns for the period April 20, 2010 through April 5, 2011. Results show that the most significant impact of the oil spill to the stock price was over the first 34 days of the event period. This study estimates a significant negative impact of $38 \%$ to $41 \%$ in share value for BP during this event period.
\end{abstract}

Keywords: Deepwater Horizon Drilling Platform; Gulf Oil Spill; British Petroleum

\section{INTRODUCTION}

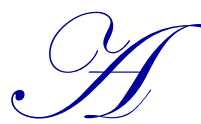

round 10 p.m. on Tuesday April 20, 2010, the oil rig known as "Deepwater Horizon" exploded and caught fire. The rig belonged to Transocean, who was working for British Petroleu (BP). The Deepwater Horizon was located about forty-two miles southeast of Venice, Louisiana, in about 5,000 feet of water. One hundred twenty-six people were on the rig when it exploded and eleven people were declared dead as they were not found. The explosion was thought to be caused by a swell of pressure which was brought on by burning oil and gas pushing upward. The fire that occurred from the blast lasted about thirty-six hours until the rig finally sank. The uncapped well leaked oil and a huge oil slick formed. On April 25, the Coast Guard believed the rig was leaking about 1,000 barrels of crude oil per day. In order to stop the oil leak, the Coast Guard, BP and oil service companies developed a plan to use underwater vehicles to install a blowout preventer. The water depth at the site was too deep and the pressure from the leaking well was too great so the plan did not succeed. A few days later, the Coast Guard changed their estimate of the daily oil leakage and raised the number to approximately 5,000 barrels of crude oil per day. BP accepted responsibility and proposed to stop the spill by drilling a relief well. BP predicted it would take about two to three months to complete relief well. The relief well was put in action and on May 5, BP announced that one of the three leaks was closed off. Even though one leak was closed, it did not have a great effect on stopping the oil from spilling in the Gulf. BP felt the intensifying pressure to stop the leak once oil became visible on the Louisiana coast at the uninhabited barrier islands of the Breton National Wildlife Refuge. BP intensified its efforts to try to cap the leak with a new approach. BP attempted placing a containment dome, but it too failed due to frozen hydrocarbons blocking the valve. By this point in time, the original fishing ban was increased in size and extended to May 17. On May 9, BP declared a new idea to try to stop the leak. They attempted to plug the well by using old tires and gold balls, which is known as "junk shot." This approach was also not successful. 
From May 11through May 12 the executives of the three major companies that were involved in the Deep Water Drilling operations; BP, Transocean, and Halliburton testified in Washington for at congressional hearing. The Senate Energy chairman stated the explosion was due to technical, human, and regulatory errors which meant that all three companies were at fault for the explosion. The three executives began to blame each other as the major cause of the spill. However, the United States Interior Secretary Ken Salazar declared that BP is responsible for paying the salaries of the out of work employees due to the moratorium on deep sea drilling. After meeting with White House officials, BP announces it would pay $\$ 100$ million to those workers affected by the moratorium. From June 16 to June 22, BP CEO Tony Hayward and BP Chairman Carl-Henric Svanberg develop a plan to pay damage claims for those affected by the oil spill. The two executives meet with White House officials and established a damage fund of $\$ 20$ billion. By early August the United States government reports approximately 4.9 million barrels of oil had spilled into the Gulf of Mexico. Finally, on September 19 a drilled relief well allowed Halliburton to close off the leaking well with cement.

The losses and damages from the catastrophic explosion of the Deepwater Horizon are tremendous. Eleven people died, the rig itself which was a total lost cost over $\$ 540$ million dollars and about 5 million barrels of oil was spilled into the Gulf of Mexico. The oil spill had an extensive economic impact to the Gulf States. A drilling moratorium was put into place by the Obama Administration putting thousands of oil field workers and employees in related industries that benefited from the drilling industry out of work. The fishing industry for much of the Gulf Coast was closed. Tourism for much of the Gulf Coast was down hurting restaurants, hotels, parks, etc. Also, the lower economic activity and higher unemployment caused by the spill resulted in a significant reduction in tax revenues for local and state governments across the gulf. The total economic impact has not been scientifically estimated but it could be over $\$ 100$ billion. BP is expected to pay out over $\$ 20$ billion in damages to parties affected by the spill. (Searcey).

\section{METHODOLOGY}

Efficient market theory assumes that security prices reflect all currently available information, and as such a price change is the result of new information or a reinterpretation of old information. Therefore, the importance of an event of interest, say an oil spill or dividend change, can be measured by examining price changes during the period in which the event occured. An event study methodology is designed to measure the impact of an event of interest on stock returns. Event studies have been used in a large variety of studies, including mergers and acquisitions, earnings announcements, debt or equity issues, corporate reorganizations, investment decisions and corporate social responsibility (MacKinlay 1997; McWilliams \& Siegel, 1997).

Event study methodology is used in this study to determine the impact of BP oil spill on the value of the firm. Analyzing the impact of BP oil spill or for that matter any particular event is more difficult than it might at first appear. On any day, stock prices respond to a wide range of economic news such as updated forecasts for GDP, inflation rates, interest rates, or corporate profitability. Isolating the part of a stock price movement that is attributable to a specific event starts with a proxy for what the stock's return would have been in the absence of the event. The abnormal return due to the event is estimated as the difference between the stock's actual return and this benchmark.

Calculating an event's abnormal return is accomplished by adjusting for the market return. This event study approach is central to event study methodology. So, the selection of the benchmark to use or the model to measure normal returns is therefore important to conduct an event study. Two methodologies for estimating the benchmark return are used in this study. The first approach estimates normal returns using an asset pricing model such as the CAPM. This is a single index model. The second approach uses a multifactor model such as the FamaFrench three-factor model.

The measure of the impact of the oil spill event on BP's shareholders is estimated by calculating the abnormal return for BP's common stock beginning when the market can attempt to price the implications of the spill trough various time periods. The announcement date is the date when the public became informed of the spill and can value the event through market actions. The event occurred around $10 \mathrm{pm}$ on April 20, 2010 when the New York Stock Exchange was closed. The start or announcement date is April 21, 2010. The abnormal returns of BP stock are computed and the statistical significance is assessed to determine the impact of the event. 
The abnormal return for the announcement date may be a poor indicator of the total impact of an event. If the event's total implications cannot be identified, information about the event is incomplete or if the event is dynamic and actually multi period phenomena, the cumulative abnormal returns for multiple periods should be calculated.

In case of an event such as BP's oil spill where the consequences and impact of the event are not know and are difficult to estimate the financial implications a better indicator of the events true impact to the shareholders is the measure of the cumulative abnormal return. Cumulative abnormal return (CARs) will capture the daily price adjustments that are reflecting the new information. CARs are simply the sum of all abnormal returns over the time period of interest. The cumulative abnormal return thus captures the total firm-specific stock movement for an entire period when the market might be responding to what the event consequences will be.

On the announcement day, called day 0 , an abnormal return is expected to occur reflecting what the market believes the consequences of the event to the company and its shareholders. It is expected that immediately after the announcement date the Cumulative Abnormal Return (CAR) no longer increases or decreases significantly. This is in accord with the efficient market hypothesis. Once the new information became public, the stock prices react almost immediately in response to the good (or bad) news. With prices once again fairly set, reflecting the effect of the new information, further abnormal returns on any particular day are equally likely to be positive or negative. In fact, for a sample of many firms, the average abnormal return should be extremely close to zero, and thus the CAR will show neither upward nor downward drift. This is precisely the pattern expected. However, if the information on the event day does not completely describe the potential consequences or if new additional significant information follows after the event day, stock prices will continue to adjust to find an equilibrium reflecting the information set.

Event study methodology has become a widely accepted tool to measure the economic impact of a wide range of events. For example, the SEC regularly uses event studies to measure illicit gains captured by traders who may have violated insider trading or other securities laws. ${ }^{1}$ Event studies are also used in fraud cases, where the courts must assess damages caused by a fraudulent activity.

\section{A Single Index Model}

A single-index model such as Capital Asset Pricing Model, holds that stock returns are determined by a market factor and a firm-specific factor. The stock return, $r_{B P t}$, during a given period $t$, is expressed mathematically as

$r_{B P t}=\alpha+\beta r_{I E O t}+e_{t}$

Where:

$r_{I E O t}$ is the Oil market's (iShares Dow Jones US Oil \& Gas Ex Index (IEO) rate of return during the period $e_{t}$ is the part of a security's return resulting from firm-specific events,

$\beta$ measures sensitivity to the Oil market return, and

$\alpha$ is the average rate of return the stock would realize in a period with a zero market return.

The above Capital Asset Pricing Model provides a decomposition of $r_{B P t}$ into market and firm-specific factors. The firm-specific or abnormal return may be interpreted as the unexpected return that results from the event. The residual, $e_{t}$, that is, the component presumably due to the event in question, is the stock's return over and above what one would predict based on broad market movements in that period, given the stock's sensitivity to the market. The abnormal return is simply $e_{t}$.

To determine the model's intercept and slope, daily returns for the period of January 2, 2008 through April 19, 2010 (578 days). Returns for Shares of the Dow Jones US Oil \& Gas Ex Index (IEO) is used as independent variable and returns on BP is the dependent variable. These estimates are respectively, $0.004891 \%$ and 0.597684 . 


\section{The Multifactor Model}

A second approach, the Fama-French Model (1970) which is a multi-factor model was used to measure abnormal performance. Fama and French started with the observation that two classes of stocks have tended to do better than the market as a whole: (i) small caps and (ii) stocks with a high book-value-to-market ratio (customarily called "value" stocks; their opposites are called "growth" stocks). Fama-French suggest a three factor model utilizing the size of the firm (SMB), book to market ratio (HML) and the risk premium on the market portfolio as determinants of asset returns. The excess stock return for the Fama-French Model, $r_{B P t}-r_{f t}$, during a given period $t$, is expressed mathematically as:

$r_{B P t}-r_{f t}=\alpha+\beta(\mathrm{Rm}-\mathrm{Rf})+\beta_{s} S M B+\beta_{v} H M L++e_{t}$

Where:

$r_{B P t}-r_{f t}$ is the excess return on BP stock

$\alpha$ is the average rate of return the stock would realize in a period with a zero market return.

$\beta$ measures sensitivity to the excess return on the market, (Rm - Rf)

$\beta_{s}$ measures the sensitivity to SMB (Small - Big Capitalization) factor

$\beta_{v}$ measures the sensitivity to HML (High - Low Book-to-Market) factor

$e_{t}$ is the part of a security's return resulting from firm-specific events,

Fama French factors have been estimated based on January 2, 2008 through April 19, 2010 (578 days) daily return data and the multifactor model results are:

Estimated Excess Return $=0.044066+0.242766\left(\mathrm{R}_{\mathrm{m}}-\mathrm{R}_{\mathrm{f}}\right)+0.194238 \mathrm{SMB}+0.28344 \mathrm{HML}$

Abnormal returns can then be calculated by subtracting estimated excess return on BP from actual excess return on BP during the event period from April 20 through June 7, 2010.

\section{DATA}

Daily return data on BP, IEO, (Rm - Rf), SMB, and HML for the period January 2, 2008 through April 19, 2010 (578 days) are used to estimate the single index model and the Fama French model. Abnormal returns are then calculated over the period April 20 through April 5, 2011.

\section{RESULTS}

The impact of Gulf Oil spill on BP shareholders is estimated by calculating the abnormal return on BP stock from the April 21, 2010 through several different time periods. The abnormal return for the actual day of the blow out but it was after the stock market had closed was $0.470379 \%$ based on single-index model and it is $1.113158806 \%$ based on Fama-French multifactor model. The day after the blow out when the market could react to the event, the return using the single index model was -.4188606 and -.8882352 for the Fama-French model.

The better indicator is the measure of the cumulative abnormal return which is simply the sum of all abnormal returns over the time period of interest. The cumulative abnormal return thus captures the total firmspecific stock movement for an entire period when the market might be responding to new information. The "event window" generally indicates the number of days before and after the announcement date over which the abnormal returns is accumulated. We chose conservatively a one-year time horizon after the announcement date to capture future abnormal performance and the cumulative abnormal return from April 20, 2010 through April 5, 2011 (for 244 days) was $-32.6474 \%$ as shown in table 1 . Results in table 2 show that the most significant impact of the oil spill was over the first 34 days. 
Table 1

Cumulative abnormal returns based on Single Index Model

\begin{tabular}{|c|c|}
\hline Time & Cumulative Abnormal Return\% \\
\hline $4 / 20$ through $4 / 23 / 2010$ & -2.127220013 \\
\hline $4 / 26 / 2010$ to $6 / 7 / 2010$ & -35.9833839 \\
\hline $6 / 8 / 2010$ to $7 / 20 / 2010$ & 0.001274368 \\
\hline $7 / 21 / 2010$ to $8 / 31 / 2010$ & 2.908585656 \\
\hline $9 / 1 / 2010$ to $10 / 13 / 2010$ & 8.077124359 \\
\hline $10 / 14$ to $11 / 24 / 2010$ & -3.627663693 \\
\hline $11 / 26 / 2010$ to $1 / 7 / 2011$ & 5.059632192 \\
\hline $1 / 10 / 2011$ to $2 / 22 / 2011$ & -1.670130612 \\
\hline $2 / 23 / 11$ through $4 / 5 / 11$ & -5.28564026 \\
\hline Total Cumulative residual for $4 / 20 / 2010$ through $4 / 5 / 2011$ & -32.6474219 \\
\hline
\end{tabular}

Table 2

\begin{tabular}{|c|c|c|c|}
\hline \multicolumn{4}{|c|}{ Abnormal Returns based on Single Index Model } \\
\hline Date & AR \% & Date & AR \% \\
\hline 4/20/2010 & 0.47037902 & $5 / 13 / 2010$ & -0.498167794 \\
\hline $4 / 21 / 2010$ & -0.4188605 & $5 / 14 / 2010$ & -1.328630109 \\
\hline $4 / 22 / 2010$ & -1.2821225 & $5 / 17 / 2010$ & 0.374304956 \\
\hline $4 / 23 / 2010$ & -0.896616 & $5 / 18 / 2010$ & -2.332553482 \\
\hline $4 / 26 / 2010$ & -2.9879568 & $5 / 19 / 2010$ & 0.682405314 \\
\hline $4 / 27 / 2010$ & -0.7625821 & $5 / 20 / 2010$ & 1.482895358 \\
\hline $4 / 28 / 2010$ & 1.33413161 & $5 / 21 / 2010$ & -3.027099406 \\
\hline $4 / 29 / 2010$ & -8.2478938 & $5 / 24 / 2010$ & -2.983968116 \\
\hline 4/30/2010 & -0.5641237 & $5 / 25 / 2010$ & 1.299776028 \\
\hline $5 / 3 / 2010$ & -4.7685382 & $5 / 26 / 2010$ & -0.691874623 \\
\hline $5 / 4 / 2010$ & 3.42476891 & $5 / 27 / 2010$ & 3.719144384 \\
\hline $5 / 5 / 2010$ & 2.71982318 & $5 / 28 / 2010$ & -4.750713364 \\
\hline $5 / 6 / 2010$ & 0.83044064 & $6 / 1 / 2010$ & -12.09581739 \\
\hline $5 / 7 / 2010$ & -0.671341 & $6 / 2 / 2010$ & -0.29711676 \\
\hline $5 / 10 / 2010$ & -3.5565932 & $6 / 3 / 2010$ & 2.678925362 \\
\hline $5 / 11 / 2010$ & 0.45425274 & $6 / 4 / 2010$ & -2.874158193 \\
\hline $5 / 12 / 2010$ & -2.0092135 & $6 / 7 / 2010$ & -0.535910804 \\
\hline CAR for first 17 days \% & -16.932045 & CAR for second 17 days \% & -21.17855864 \\
\hline Total CAR for 34 days & -38.110604 & Std Dev of AR 34 days & 3.109177653 \\
\hline
\end{tabular}

\section{Statistical significance}

Two t-statistics are frequently used to test the statistical significance of the CAR, one using the time series mean abnormal returns as in Brown and Warner (1980, 1985), and the other using the calendar-time abnormal 
returns as in Jaffe (1974) and Mandelker (1974). The t-statistics using the time-series approach are computed as follows:

$$
\mathrm{t}=\frac{\sum_{\mathrm{t}=1}^{\mathrm{t}=34} \overline{\mathrm{AR}_{\mathrm{t}}}}{\left(\sum_{\mathrm{t}=1}^{\mathrm{t}=34} \mathrm{~S}^{2} \overline{\mathrm{AR}_{\mathrm{t}}}\right)^{\frac{1}{2}}}
$$

T statistics for both single index model, as well as Fama-French model reveal that CAR over 34 days is significant.

Table 3

Abnormal Returns based on Fama-French Model

\begin{tabular}{|c|c|c|c|}
\hline \multicolumn{4}{|c|}{ Using Fama French multifactor Model, Residuals for 34 days 4/20 through 06/07/2010 } \\
\hline Date & AR \% & Date & AR \% \\
\hline $4 / 20 / 2010$ & 1.113158806 & $5 / 13 / 2010$ & -0.5843733 \\
\hline $4 / 21 / 2010$ & -0.88823522 & $5 / 14 / 2010$ & -1.9031636 \\
\hline $4 / 22 / 2010$ & -1.343375652 & $5 / 17 / 2010$ & -0.5400562 \\
\hline $4 / 23 / 2010$ & 0.077665903 & $5 / 18 / 2010$ & -1.9986633 \\
\hline $4 / 26 / 2010$ & -3.308017513 & $5 / 19 / 2010$ & 0.07897104 \\
\hline $4 / 27 / 2010$ & -1.834788545 & $5 / 20 / 2010$ & -0.0807165 \\
\hline $4 / 28 / 2010$ & 1.591447923 & $5 / 21 / 2010$ & -2.3123044 \\
\hline $4 / 29 / 2010$ & -8.924967085 & $5 / 24 / 2010$ & -4.1735931 \\
\hline $4 / 30 / 2010$ & 0.020339896 & $5 / 25 / 2010$ & 1.57003455 \\
\hline $5 / 3 / 2010$ & -4.405377331 & $5 / 26 / 2010$ & -0.5969483 \\
\hline $5 / 4 / 2010$ & 2.944969103 & $5 / 27 / 2010$ & 5.54187557 \\
\hline $5 / 5 / 2010$ & 1.764859905 & $5 / 28 / 2010$ & -4.9682306 \\
\hline $5 / 6 / 2010$ & -0.231333956 & $6 / 1 / 2010$ & -13.906296 \\
\hline $5 / 7 / 2010$ & -1.76960457 & $6 / 2 / 2010$ & 2.29712161 \\
\hline $5 / 10 / 2010$ & -2.255711896 & $6 / 3 / 2010$ & 3.99690878 \\
\hline $5 / 11 / 2010$ & -0.232960928 & $6 / 4 / 2010$ & -4.1323313 \\
\hline $5 / 12 / 2010$ & -1.27560561 & $6 / 7 / 2010$ & -0.3069295 \\
\hline CAR for first 17 days $\%$ & -18.95753677 & CAR for second 17 days $\%$ & -22.018694 \\
\hline \multicolumn{2}{|c|}{ From $4 / 20 / 2010$ through $6 / 7 / 2010$, CAR $\%$} & & -40.976231 \\
\hline
\end{tabular}

Consistent across two different normal return models - Single Index and Fama French - used to estimate abnormal returns, we find large negative abnormal returns during the event period. Results show declining Cumulative Abnormal Returns (CAR's) after announcement date and predictably declining CAR's violate the efficient market hypothesis. A profit opportunity is possible by short-selling BP stock on the event date before the prices are predicted to fall. Second, BP announcements during the event period seem to have no significant effect on the paths of cumulative abnormal returns. We observe increasingly negative CAR values during the post announcement period beyond $t=1$. One explanation for this observation might be that the market shows an incomplete reaction to the announcement leading to further price adjustments during post announcement period.

\section{CONCLUSIONS}

This paper studied the economic impact of a very damaging and unanticipated event, the huge oil spill on BP's stock price and how it impacted the return to their shareholders. Assuming that there were no other confounding events during the period of interest, this study finds a significant negative impact of $38 \%$ to $41 \%$ in share value for BP's shareholders the first 34 days after the spill. During the first three months following the blowout, the common stock declined in value by more than one-half and resulting in the loss in market value of over $\$ 43,000,000,000$. 
The market was closed when the spill occurred on April 20, 2010. BP's shares had closed that day at $\$ 60.48$. The stock price slid almost continuously for the next three months with only small price rebounds or upticks. BP's stock price hit the low on June 25, 2010 at $\$ 27.32$. Prices of BP have since increased over the two years at a very small rate and have generally trade between the mid to high $\$ 40$ 's. The tragedy on April 20, 2012 has cost BP shareholders dearly. Besides the huge decline in market value, BP suspended it common stock dividend for almost two years.

\section{AUTHOR INFORMATION}

Denis O. Boudreaux is an associate professor at the University of Louisiana at Lafayette and teaches the financial management case course and the MBA advanced finance course. Some of his research interests include capital markets, characteristics of the oil and gas industry, forensic economics, capital budgeting and valuing and measuring the cost of capital of small privately owned firms. He has published in many refereed journals including Business and Economic Review, Journal of Business \& Economics Research, Journal of Petroleum Accounting and Financial Management, and the Journal of Economics and Finance. Dr. Boudreaux is a practicing forensic economist and testifies in personal injury and commercial damage cases. E-mail: denis.boudreaux@lusfiber.net (Corresponding author)

S.P. Rao is a full professor at the University of Louisiana at Lafayette. He teaches investment and portfolio management courses. His research specialty is in the fields of investments, portfolio theory and capital market efficiency. Dr. Rao has published in many academic journals such as Journal of Business Ethics, Global Finance Journal, Managerial Finance, Southwestern Economic Review, Journal of Economics and Finance, International Business \& Economics Research Journal and the Journal of Accounting and Finance Research. E-mail: smr8609@louisiana.edu

Dr. Praveen K. Das is an Assistant Professor of Finance at University of Louisiana at Lafayette. His research focuses on market anomalies, corporate governance, international investments, and mutual funds. His papers have been published in several peer-reviewed journals including Managerial Decision Economics, Managerial Finance, Social Responsibility Journal, International Business \& Economics Research Journal. E-mail: pkd8947@louisiana.edu

Nancy C. Rumore is an instructor in Economics at the University of Louisiana a Lafayette. She teaches the fundamentals of economics to non-business and business majors. She has published in many referred journals including The Journal of Financial and Strategic Decisions, The Journal of Bank Cost and Management Accounting, The Journal of Business and Economics Perspectives, Multinational Business Review, Atlantic Economic Journal, Journal of Economics and Finance, and The Journal of Restaurant and Foodservice Marketing. E-mail: ncr2076@louisiana.edu

\section{REFERENCES}

1. Brown SJ, Warner JB. Measuring security price performance. Journal of Financial Economics, 1980; 8: 205-58.

2. Brown SJ, Warner JB. Using daily stock returns: the case of event studies. Journal of Financial Economics, 1985; 14:3-31.

3. MacKinlay, A. C. "Event Studies in Economics and Finance," Journal of Economic Literature Vol. XXXV, Issue 1 (March 1997).

4. Mandelker G. Risk and return: the case of merging firms. Journal of Financial Economics, 1974; 1:303-36.

5. Jaffe JF. Special information and insider trading. Journal of Business, 1974; 47:410-28.

6. McWilliams, A. and Siegel, D. "Event studies in management research: Theoretical and empirical issues" Academy of Management Journal, Vol. 40, No. 3, (1997) 
BP Stock price Vs. S\&P 500 Stock Price 1

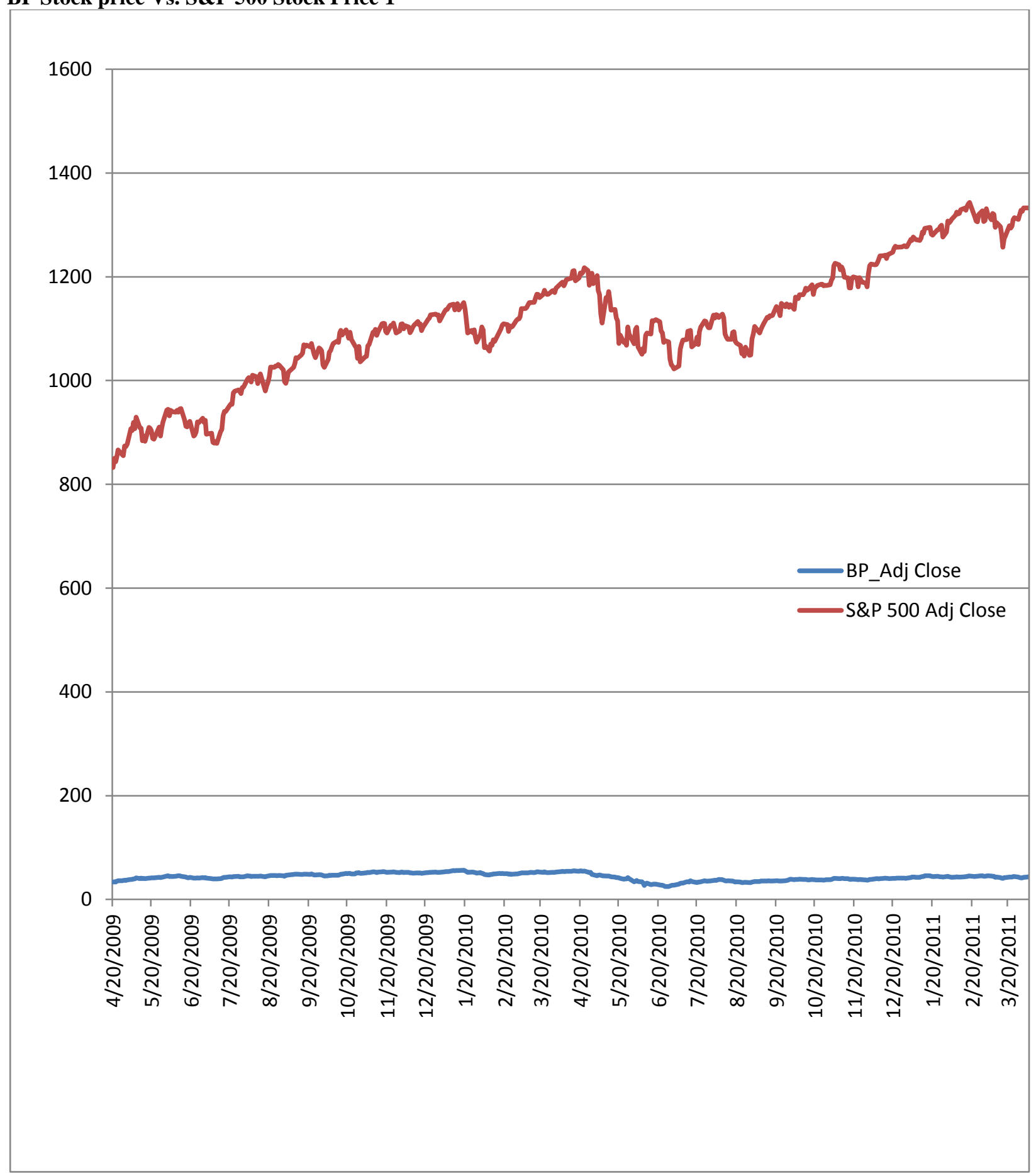

